\title{
Characteristics and Productivity of Volcanic Rock Aquifers in the Upper Part of Blue Nile Basin, Ethiopia
}

\author{
Awoke Ayalew ${ }^{1}$, Nata T. Tafesse ${ }^{2, *}$, Miruts Hagos $^{3}$, Kitso N. Matende ${ }^{2}$ \\ ${ }^{1}$ Amhara Water Well Drilling Enterprise, Ethiopia \\ ${ }^{2}$ Department of Geology, University of Botswana, Botswana \\ ${ }^{3}$ College of Earth Sciences, Mekelle University, Ethiopia
}

Received August 13, 2019; Revised September 27, 2019; Accepted October 7, 2019

Copyright $\mathrm{C} 2019$ by authors, all rights reserved. Authors agree that this article remains permanently open access under the terms of the Creative Commons Attribution License 4.0 International License

\begin{abstract}
This study was conducted in the upper parts of the Blue Nile Basin, Ethiopia, with the objective of characterizing the different volcanic rock aquifers and evaluating their respective productivity. Geological, structural and hydrogeological methods were utilized in this study. Quaternary vesicular basalt $(27.33 \%)$ and Tertiary aphanitic basalts (72.67\%) are the two geological formations in the basin. In both cases, the weathered and fractured zones are the water bearing zones. Confined aquifer, multilayer confined aquifer and multilayer unconfined-confined aquifer are the types of aquifers identified in the basin. The computed values of the hydraulic conductivity, transmissivity and specific capacity for the multilayer unconfined-confined aquifers ranges from 0.165 to $49 \mathrm{~m} /$ day, 11.30 to $3870 \mathrm{~m}^{2} /$ day, and 0.164 to $30.968 \mathrm{l} / \mathrm{sec} / \mathrm{m}$, respectively. The computed hydraulic conductivity, transmissivity and specific capacity for the multilayer confined aquifer are 0.525 $\mathrm{m} /$ day, $10.9 \mathrm{~m}^{2} /$ day and $0.190 \mathrm{l} / \mathrm{sec} / \mathrm{m}$, respectively. The hydraulic conductivity, transmissivity and specific capacity for the confined aquifer are $6.46 \mathrm{~m} /$ day, 148 $\mathrm{m}^{2} /$ day and $1.363 \mathrm{l} / \mathrm{sec} / \mathrm{m}$, respectively. Based on the analyzed results of transmissivity and specific capacity, three aquifer potentiality groups were recognized: high potentiality aquifer, moderately potentiality aquifer and low potentiality aquifers. For sustainable groundwater management in the basin, development of groundwater should take place in the area covered by high potentiality aquifer by considering the whole thickness of the aquifers.
\end{abstract}

Keywords Aphanitic Basalts, Aquifer Potentiality, Blue Nile River, Groundwater, Specific Capacity, Transmissivity

\section{Introduction}

\subsection{General}

Water is the very essential and basic component of life. It is the most basic resource affecting municipal, agricultural and economic activities, and every development is dependent directly or in directly on water availability. Beneath the surface of the earth lies a tremendous resource that many people depend on for their day-to-day activities. This precious resource is groundwater.

Ethiopia, though it has huge amount of water resources, is frequently affected by recurrent drought, and as a result the people are not food secured. This problem exacerbated to some extent by the lack of knowledge of the available potential water resources, underutilization and mismanagement of the existing water resources together with the erratic nature of the rainfall in most parts of the country. To sustain the current economic development that the country has achieved so far, proper understanding, development and utilization of groundwater resource that makes its base on groundwater investigation is indispensable.

In the study area, the upper part of the upstream side of the Blue Nile basin, the current water source for different purposes is largely groundwater. A number of different groundwater structures were found drilled in different parts of the basin for these purposes. The development of groundwater in the basin, however, is not based on detailed hydrogeological studies that take into account the characteristics and productivity nature of the different aquifers of the basin. All the groundwater development activities are carried out based on surface geological and geophysical electrical resistivity (vertical electrical sounding) studies. The objective of the current study is to characterize the different volcanic rock aquifers and evaluate their respective productivity to fill such gaps and 
provide the necessary information for future sustainable development of groundwater in the basin.

\subsection{Location}

The study area is a small part of the upper part of Blue Nile basin which is located in the Amhara Regional State particularly in Bahir Dar City and its surroundings. Geographically, the basin is located between 309837 to $356400 \mathrm{mE}$ and 1233166 to $1288974 \mathrm{mN}$, having a total area of $1238 \mathrm{~km}^{2}$. The area is bounded by Lake Tana in the north, Tis Issat fall (Tis Abay) in the southeast and airport of Bahir Dar city in the west. The Blue Nile River crosses the basin centrally from northwest to southeast direction (Fig. 1).

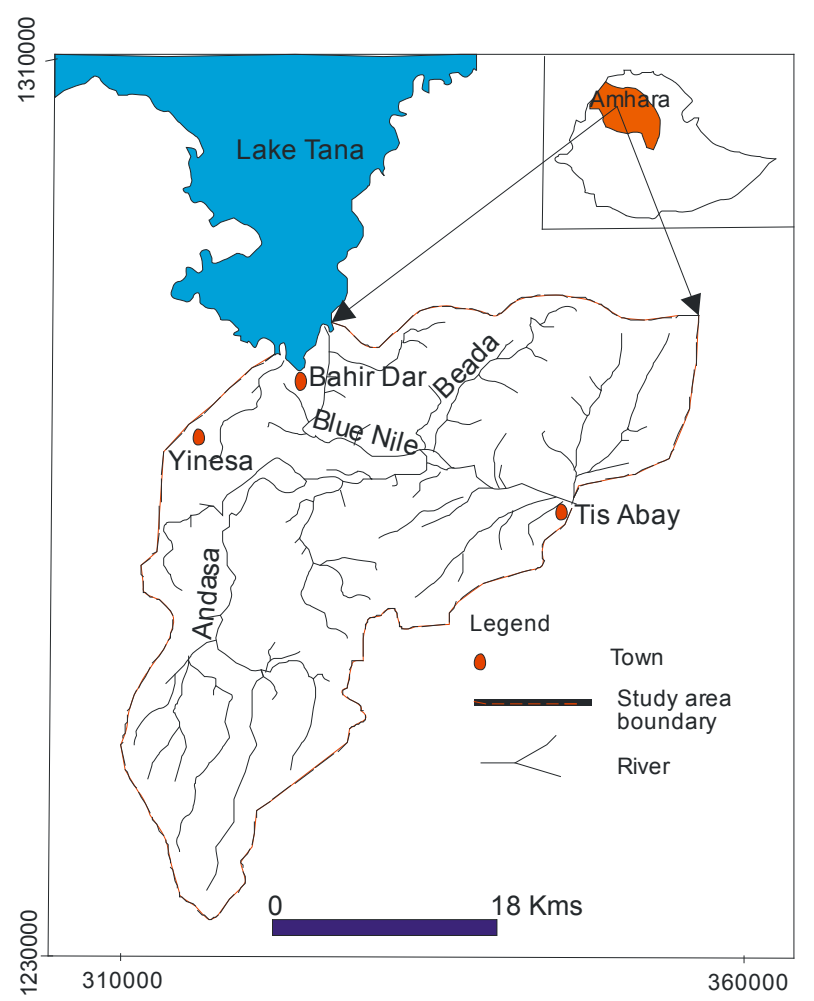

Figure 1. Location map of study area

\subsection{Physiography and Drainage Pattern}

The altitudes of the area vary from $1500 \mathrm{~m}$ to $3200 \mathrm{~m}$ above mean sea level (Fig. 2). The central, eastern and northwestern parts are characterized by gentle slope undulating and low land areas whereas the southwestern, southern and northeastern parts are highly elevated and steep slope mountainous areas.

The Blue Nile River is the main river which starts at the southern part of Lake Tana and passes through the study area and enters to a deep gorge, at the Tis Issat Hydropower Fall (Tis Abay). The catchment also drains by two major perennial streams which are tributaries of the Blue Nile River. These are Beada and Andasa rivers. Both of them join Blue Nile River at Tis Issat Hydropower Fall (Fig. 1) after flowing side by side to it in the study area.

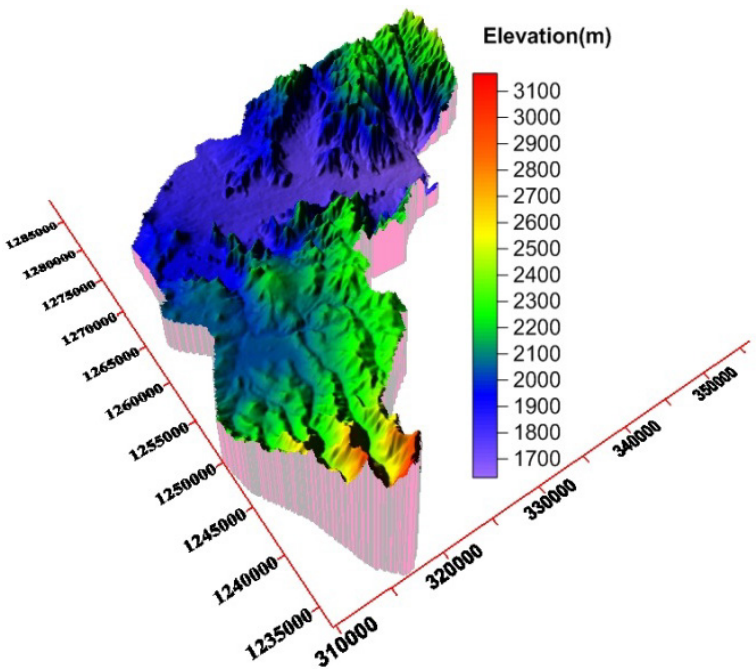

Figure 2. 3D view of DEM image of the study area

\section{Methods}

Geological and hydrogeological methods were employed to achieve the objective of this research. Delineation of the study area was done from available topo maps using different software, and then finalized by taking GPS readings at different sites of the study area for ground checking.

Geological and structural field investigation have been held by paying particular attention to the different features of volcanic rocks that made them to be a water bearing formations. Geological logs have been collected from available boreholes and shallow wells to get an idea of the different volcanic rocks with depth in the basin. The different water bearing formations were identified using geological, structural and geological logs data.

Hydrogeological field investigation was done by giving more attention on differentiating characteristics of different rock units of groundwater significance such as the degree of fracturing, space between fractures, apertures, thickness of fracture zones, degree of weathering, thickness of weathering zones, the type and degree of secondary filling in the fractures, and the thickness of the formations. The role of each geological formation in terms of hydrogeological units was examined. Inventory of boreholes, shallow wells, hand dug wells and springs were held as part of the hydrogeological investigation. From the data of boreholes, geological logs and hydrogeological field investigations, hydrogeological logs have been prepared to determine the thickness of the aquifer and also for characterizing the nature of each aquifer. Hydraulic properties of the aquifer were determined using the pumping test data. Pumping test data from the existing boreholes were collected and analyzed using Thies, Cooper-Jacob and Thies recovery methods by AquiferTest v3.5 software. 

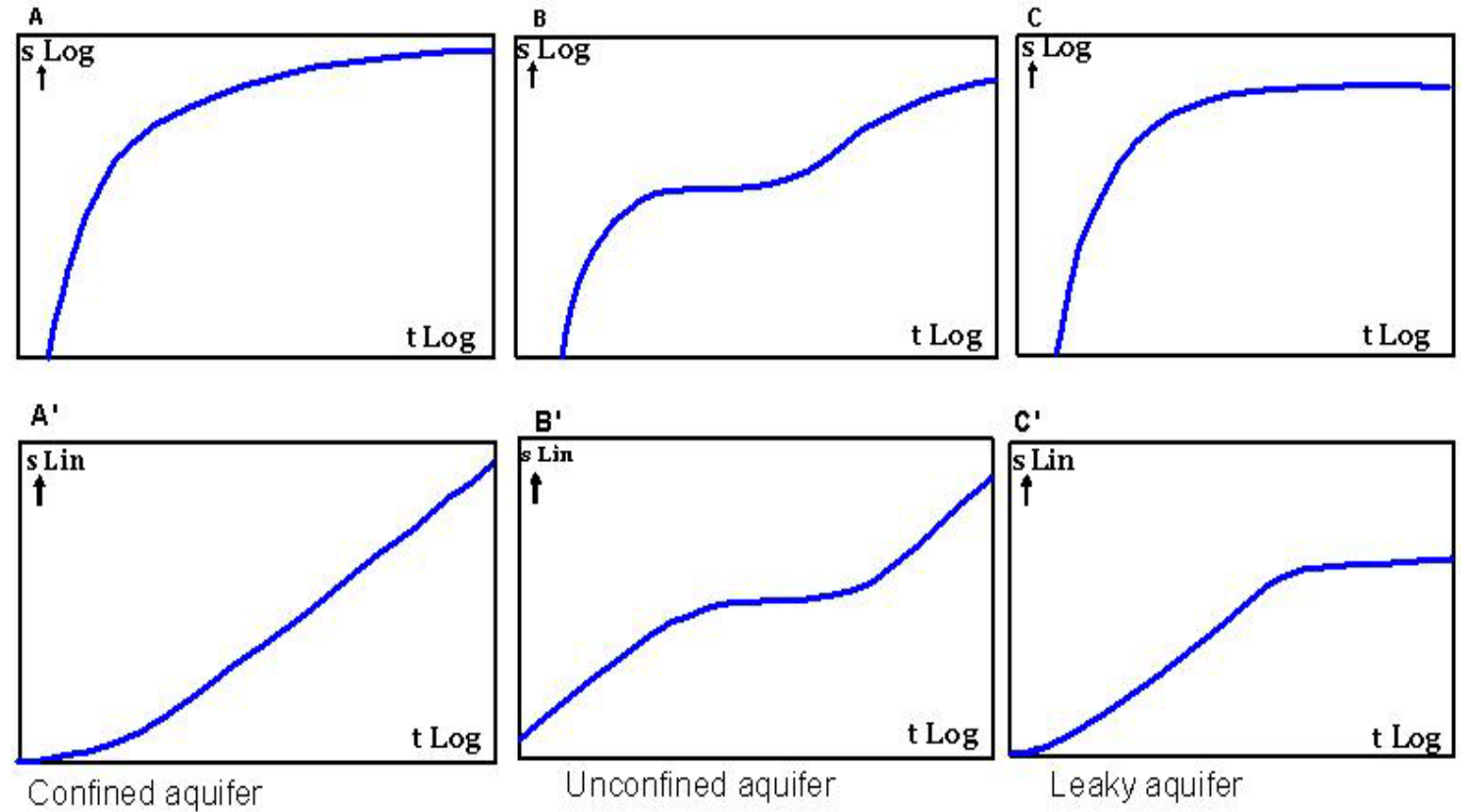

Figure 3. Log-log and Semi-Log plots of the theoretical drawdown relationship

To determine the different aquifer types, plots of pumping test data on semi-log scale (specialized plot) and Log-Log scale (diagnostic plot) were prepared for different deep wells and the drawdown behavior were compared with the various theoretical models. Theoretical models comprise the type of aquifer and initial and boundary conditions [1]. According to this author, specialized plots are specific to a given flow system. Diagnostic plot allows the dominating flow regimes to be identified.

Şen [2] scheme was used to classify the different aquifers of the study area into different class of potentiality. This scheme of classification is given in the table below.

Table 1. Classification of wells based on their transmissivity and specific capacities (Source: Şen [2])

\begin{tabular}{|c|c|c|c|}
\hline $\begin{array}{l}\text { Transmissiv } \\
\text { ity }\left(\mathrm{m}^{2} / \text { day }\right)\end{array}$ & Potentiality & $\begin{array}{c}\text { Specific } \\
\text { capacity }(\mathrm{Q} / \mathrm{sw}) \\
\text { in }[(1 / \mathrm{s}) / \mathrm{m}]\end{array}$ & $\begin{array}{c}\text { Well } \\
\text { productivity }\end{array}$ \\
\hline $\mathrm{T}>500$ & High & $\mathrm{Q} / \mathrm{s}_{\mathrm{w}}>5$ & $\begin{array}{c}\text { Highly } \\
\text { productive }\end{array}$ \\
\hline $50<\mathrm{T}<500$ & Moderate & $0.5<\mathrm{Q} / \mathrm{sw}<5$ & $\begin{array}{l}\text { Moderately } \\
\text { productive }\end{array}$ \\
\hline $5<\mathrm{T}<50$ & Low & $\begin{array}{c}0.05<\mathrm{Q} / \mathrm{s}_{\mathrm{w}}< \\
0.5\end{array}$ & Low productive \\
\hline $0.5<\mathrm{T}<5$ & Weak & $\begin{array}{c}0.005<\mathrm{Q} / \mathrm{s}_{\mathrm{w}}< \\
0.05\end{array}$ & $\begin{array}{c}\text { Very low } \\
\text { productive }\end{array}$ \\
\hline $\mathrm{T}<0.5$ & Very weak & $\mathrm{Q} / \mathrm{s}_{\mathrm{w}}<0.005$ & $\begin{array}{l}\text { Very weak } \\
\text { productive }\end{array}$ \\
\hline
\end{tabular}

\section{Results and Discussions}

\subsection{Geology of the Basin}

The geology of the study area consists of volcanic rocks of different ages and characteristics (Figs. 4 - 7). The oldest rock is the Tertiary flood basalt (Trap Series) and the youngest one is the Quaternary volcanic rock groups (Aden Series) [3]. In the place where it is not exposed to the surface the flood basalt is found overlain by Quaternary volcanic rock groups (Figs. 7). In the study area the flood basalt is aphanitic basalt whereas the Quaternary volcanic rocks are vesicular basalt.

The flood basalt of the study area is Ashangi basalt [4, 5 and 6] that was formed in the Ashangi Cycle (50-35 MY) of eruption [7]. It represents the earliest fissural flood basalt volcanism on the northwestern plateau of the country where the study area is located. The basalt flows are several hundreds of meters to a kilometer thick of strongly weathered, crushed, tilted basalts which lie below the major Pre-Oligocene unconformity [7]. The Ashangi basalts consist of predominantly mildly alkaline basalts with interbedded pyroclastics and rare rhyolites $[5,6,8$ and 9]. The basalts are commonly injected by dolerite sills, acidic dykes and gabbro-diabase intrusions. The flood basalt of the northwestern plateau has been described by different scholars in the past years $[3,4,5,6,7,8,9,10,11$, $12,13,14,15,16,17,18$ and 19].

The aphanitic basalt is outcropped in the north, northeastern, eastern, southeastern, southern, southwestern and central parts of the area, covering $72.67 \%$ of the total area of the basin (Fig. 6). It is characterized by different weathering, thickness and fracturing nature throughout the basin. In the place where it is exposed it shows a sequence of grayish brown color, weathered to decomposed basalt with a thickness of 1 to $5 \mathrm{~m}$ at the top followed by thin layer, reddish paleo-soil with a thickness of 0.5 to $1 \mathrm{~m}$ on the top of black, closely spaced fractured aphanitic basalt with exposed thickness of 0.5 to $4 \mathrm{~m}$ which itself underlain by black, poorly fractured (to massive) aphanitic basalt with 
unknown thickness. The boreholes drilled in these parts of the area also ratify the above mentioned nature of the basalt (Figs. $4 \mathrm{a} \& \mathrm{~b}$ ).

In the study area the Aden Series or Quaternary volcanic rocks occur related to local rift structures north-south trending extensional faults [20] and are composed of vesicular alkali basalt and cinder cones, indicating the volatile rich nature of the host magma. Locally, this basaltic unit contains a few $\mathrm{cm}$ to $1 \mathrm{~m}$ thick reddish to brown paleo soil indicating several eruption pulses (Fig. 7). Patchy trachytic volcanic mounds are locally present [21].

This basaltic unit is found overlain by 2 to $3 \mathrm{~m}$ recent sediments in the central, western, southwestern, northwestern and eastern topographically lowland area (Fig. 5) covering $27.33 \%$ of the total area of the basin (Fig. 6). In the bank of the rivers and shore of Lake Tana this unit is found outcropped in the area having different exposed thickness. The vesicular nature of the unit has a significant spatial variation and some are filled with green zeolite, calcite and quartz. In the basin, generally, the vesicular basalt is characterized by different nature of thickness, weathering and fracturing throughout the area where it is found (Figs. 5 and 7).

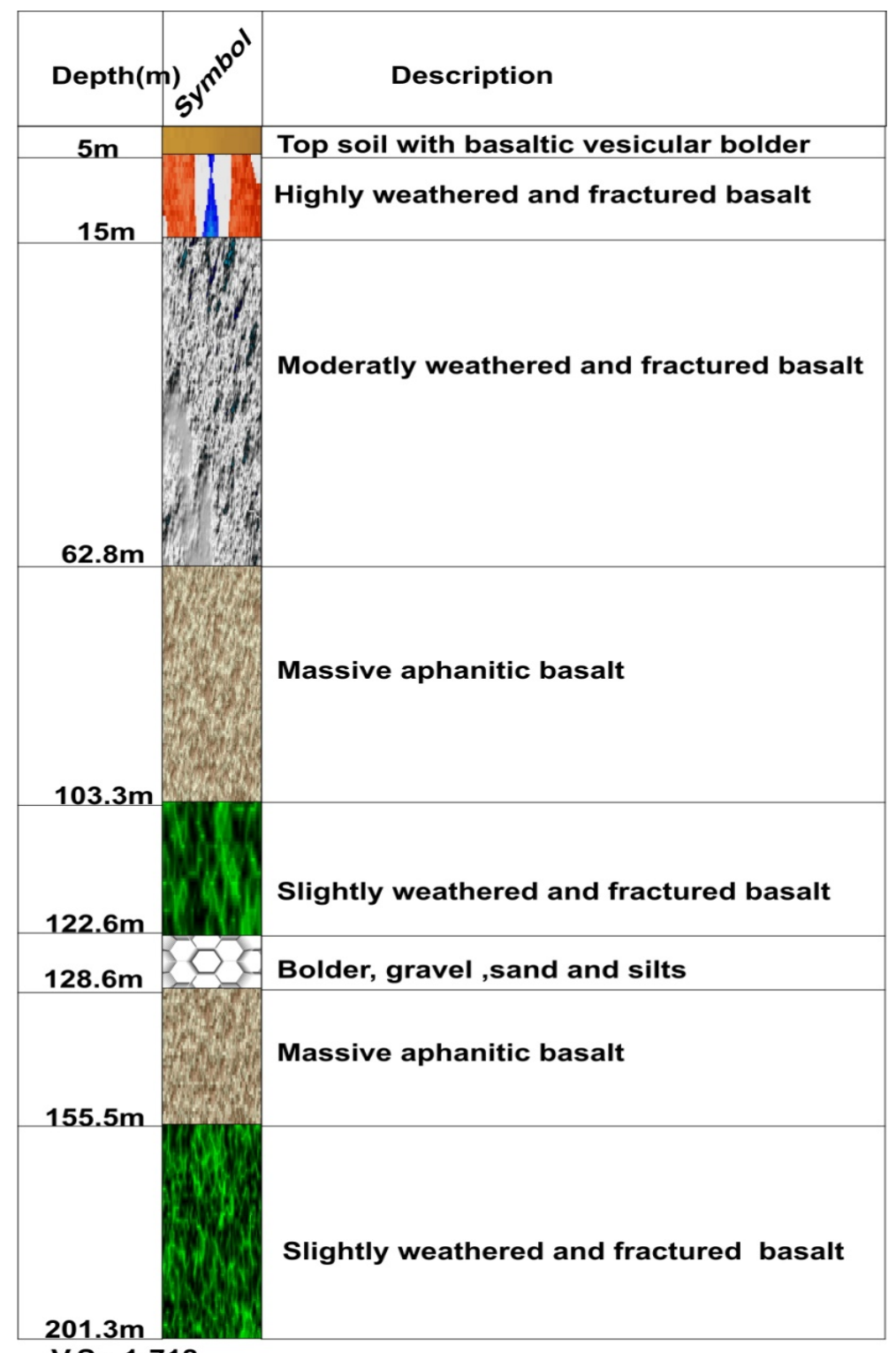

V.S.: 1:718 


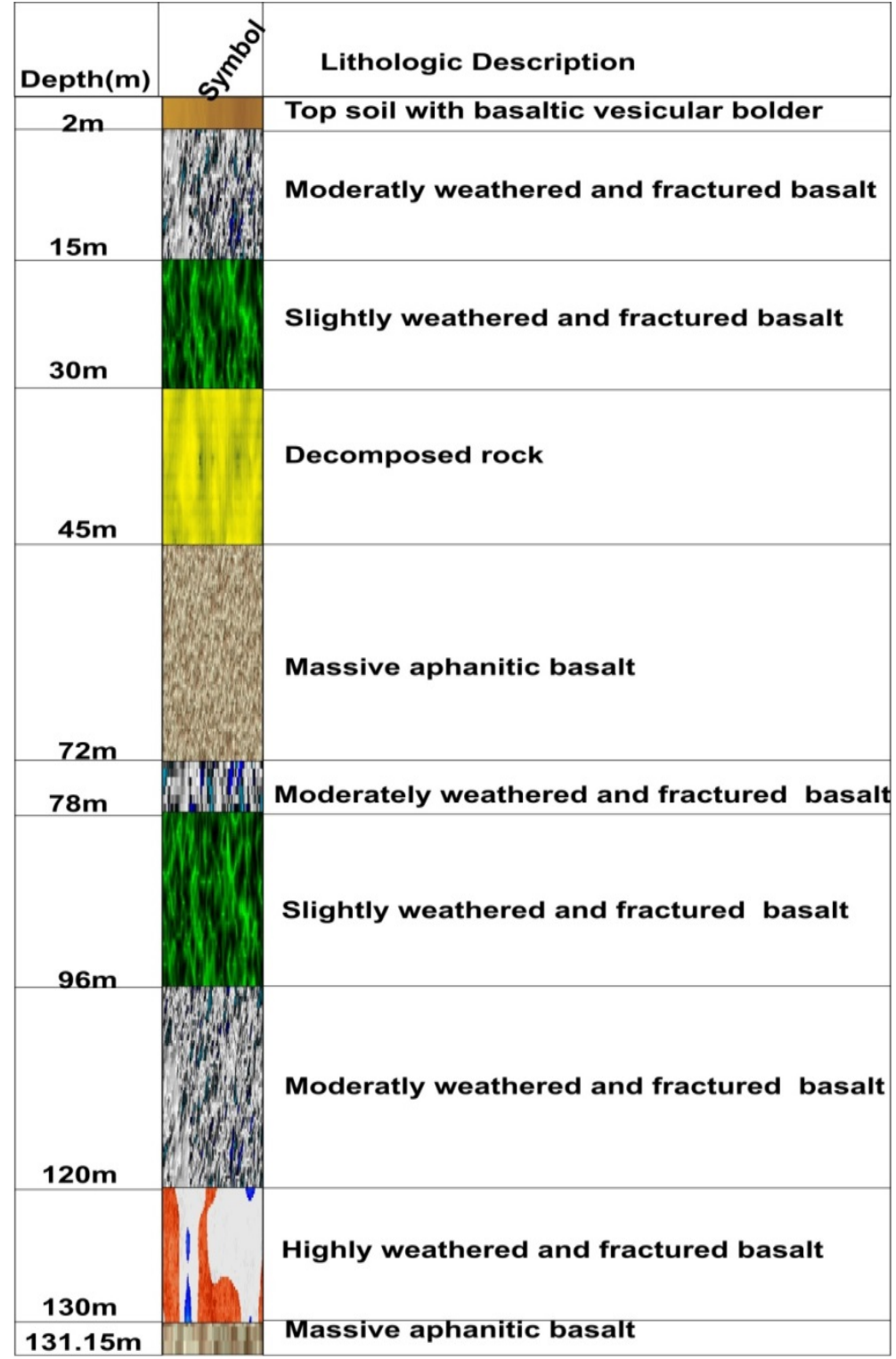

V.S.: 1:409

(b)

Source: Amhara Water Works Construction Enterprise (AWWCE)

Figure 4. (a) Lithological log of Zenzelma well (abandoned), and (b) Lithological log of Ashiraf\#2 well 


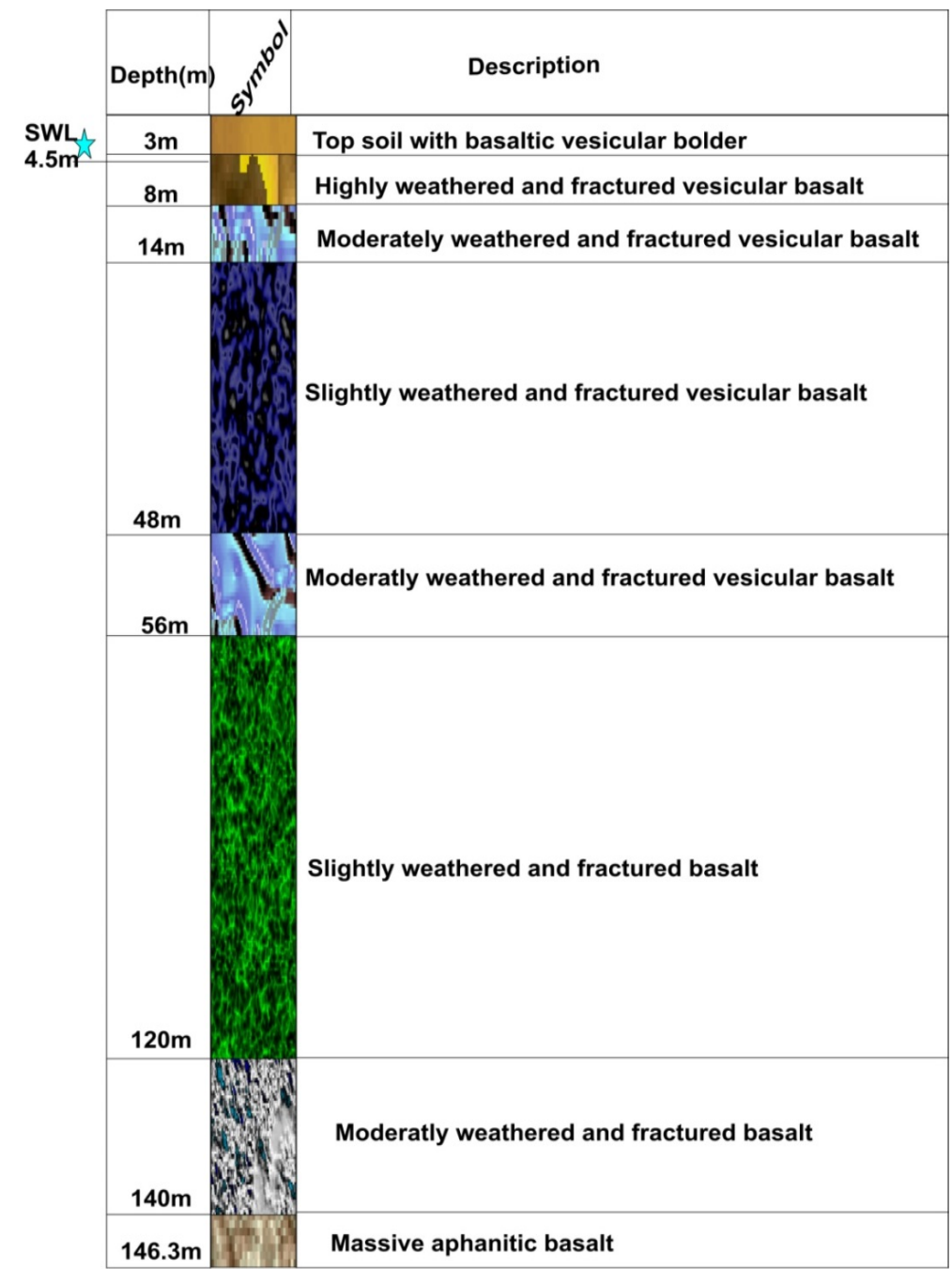

V.S.: 1:487

Source: Amhara Water Works Construction Enterprise (AWWCE)

Figure 5. Lithological log of Amhara Water Works Construction Enterprise (AWWCE) well drilled at vesicular basalt formation 

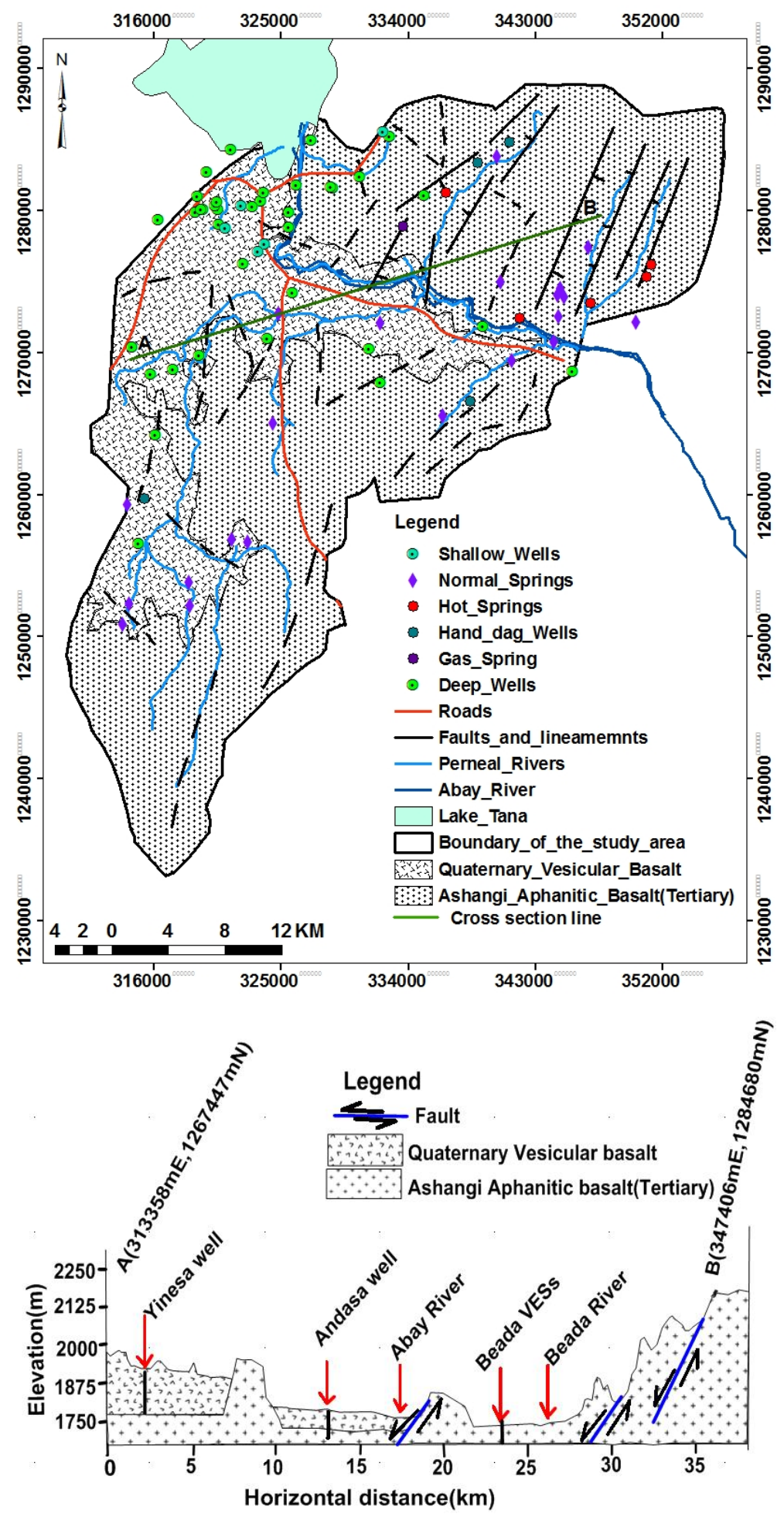

Figure 6. Geological map of the study area and cross sections along $\mathrm{AB}$ 


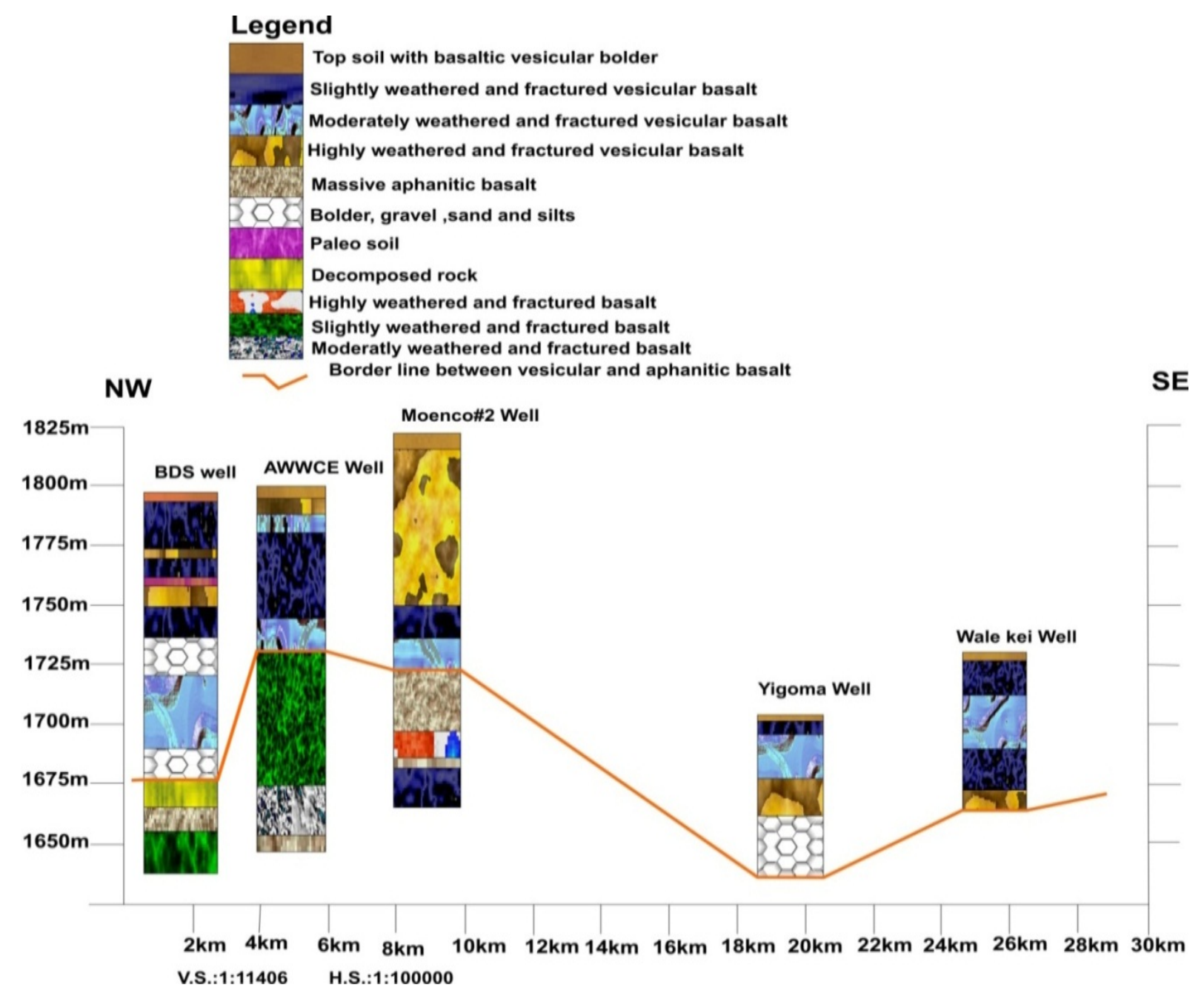

Figure 7. Thickness variation and well to well geological logs cross section along NW-SE direction of the study area

\subsubsection{Geological Structures}

The Blue Nile River and its tributaries that drain the basin are controlled by major faulting system and erosion resistances of different volcanic rocks. Geological data of structural features such as fractures, joints and faults were gathered during the field work. Digital Elevation Model (DEM) image interpretation (Fig. 2) and field observation revealed the existence of large scale normal faulting systems having NE, NE-SW and N-S orientation in the northeastern, eastern and southeastern parts of the study area. These are the major structures in the study area.

\subsection{Hydrogeology}

In this section, aquifer types, hydrogeological characteristics of different rocks, and aquifer potentiality and classification are discussed.

\subsubsection{Aquifer Types}

From the available pumping test data, a log-log and semi-log plots of drawdown versus time were constructed and the drawdown behavior was compared with the theoretical model (Figs. 8 to 10). This technique of comparison reveals the existence of three main types of aquifer in the studied area: confined aquifer, multilayer confined aquifer and multilayer unconfined-confined aquifer. 


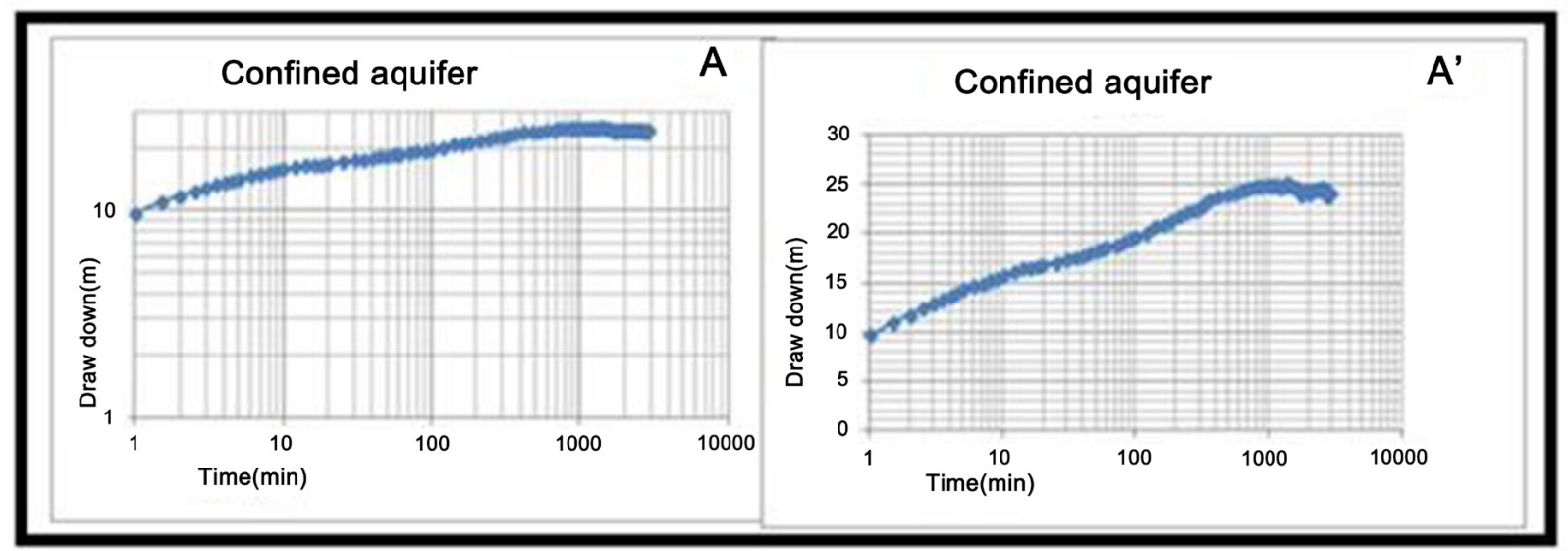

Figure 8. A is diagnostic plot and A' is specialized plots of Yigoma well

This well (Fig. 8) shows a characteristic feature of confined aquifer. It is a confined aquifer covering less extensive area in the central, western, southwestern, northwestern and eastern parts of the basin.

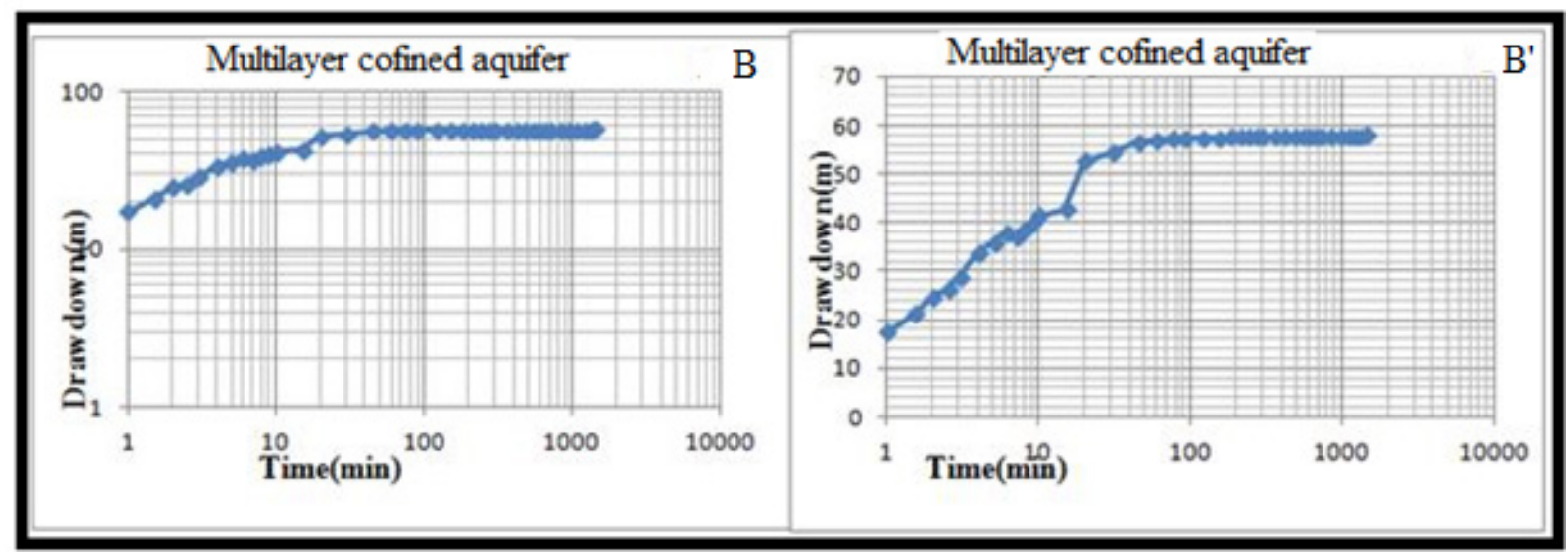

Figure 9. B is diagnostic plot and B' is specialized plot of Ashiraf\#2 well

This well (Fig. 9) shows a characteristic feature of multilayer confined aquifer. This aquifer type is found covering extensive area in the north, northeastern, eastern, southeastern, southern, southwestern and central parts of the basin.

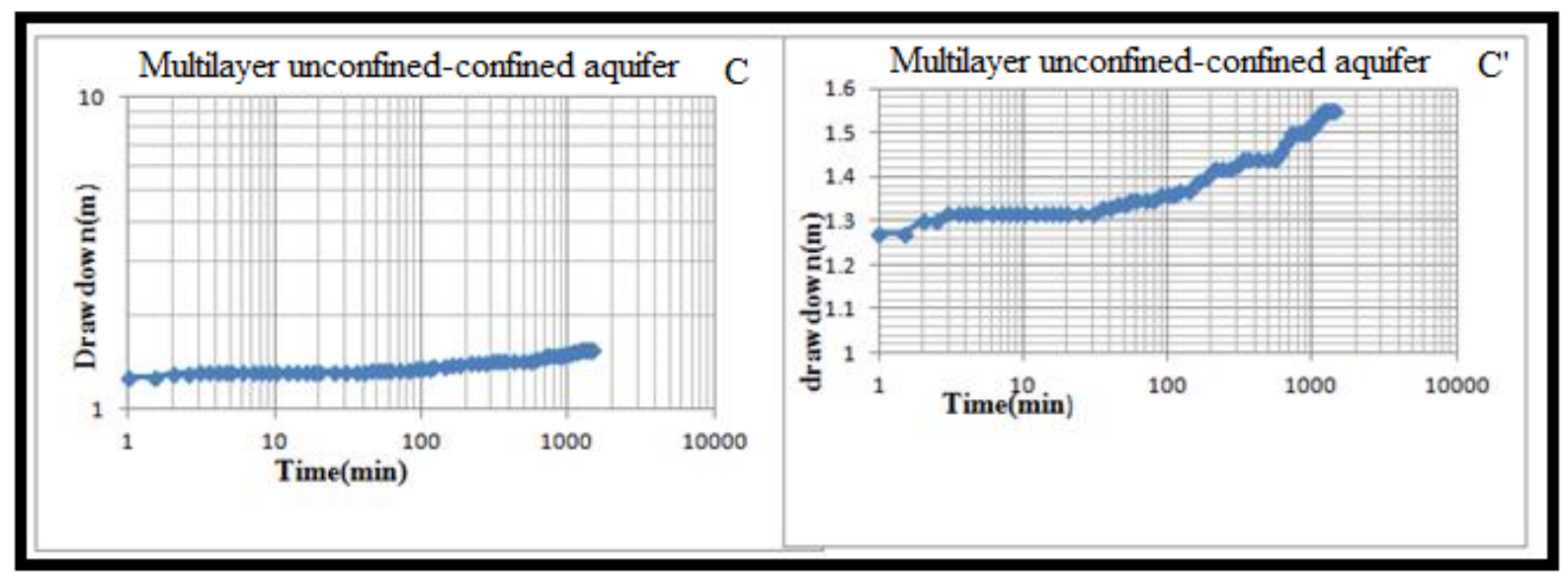

Figure 10. C is diagnostic plot and $C^{\prime}$ is specialized plots of Moenco\#2 well

This well (Fig. 10) shows a characteristic feature of multilayer unconfined-confined aquifer. This aquifer type is found covering less extensive area in the northern, north-central, western, northwestern and eastern parts of the basin. 


\subsubsection{Hydrogeological Characteristics of the Different Rock Units}

The detail hydrogeological characteristics of the two volcanic rocks are discussed below with particular reference to their water storage and transmission capacities.

\subsubsection{Aphanitic Basalt}

This unit found covering an extensive area of the basin constituting areas that ranges from topographically high (steep mountains and cliffs) to low land (valley floor): from $3200-1400 \mathrm{~m}$ asl with the majority falls between an elevation that ranges from $3200-1838 \mathrm{~m}$ asl. The rock is affected by different degree of weathering, fracturing and faulting. However, the degree of weathering, fracturing and faulting is not uniform throughout the area where the aphanitic basalt is found. In the northeastern parts the basin, where this formation is found covering mountainous area, the basalt is densely faulted, fractured and weathered and serves as a recharge zone as evidenced by existence of low to moderate yield springs at the foot of mountain hills. In the valley floor areas several boreholes and hand dug wells, which have low to very low yields, are drilled in this unit. However, since its coverage area is extensive, huge volumes of groundwater are withdrawn from it, and, in many places, it is the only reliable source of groundwater for water supply.

Even though this unit is characterized by the presence of well-developed columnar joints, the water productivity of this formation is entirely controlled by the development of secondary porosity and permeability. Weathering and fracturing due to secondary processes are the ones that enhanced the importance of this formation as a groundwater reservoir. As it is shown in the geological logs of the drilled boreholes (Fig. 11) groundwater occurred in the weathered zones and fractured zones of these formations.

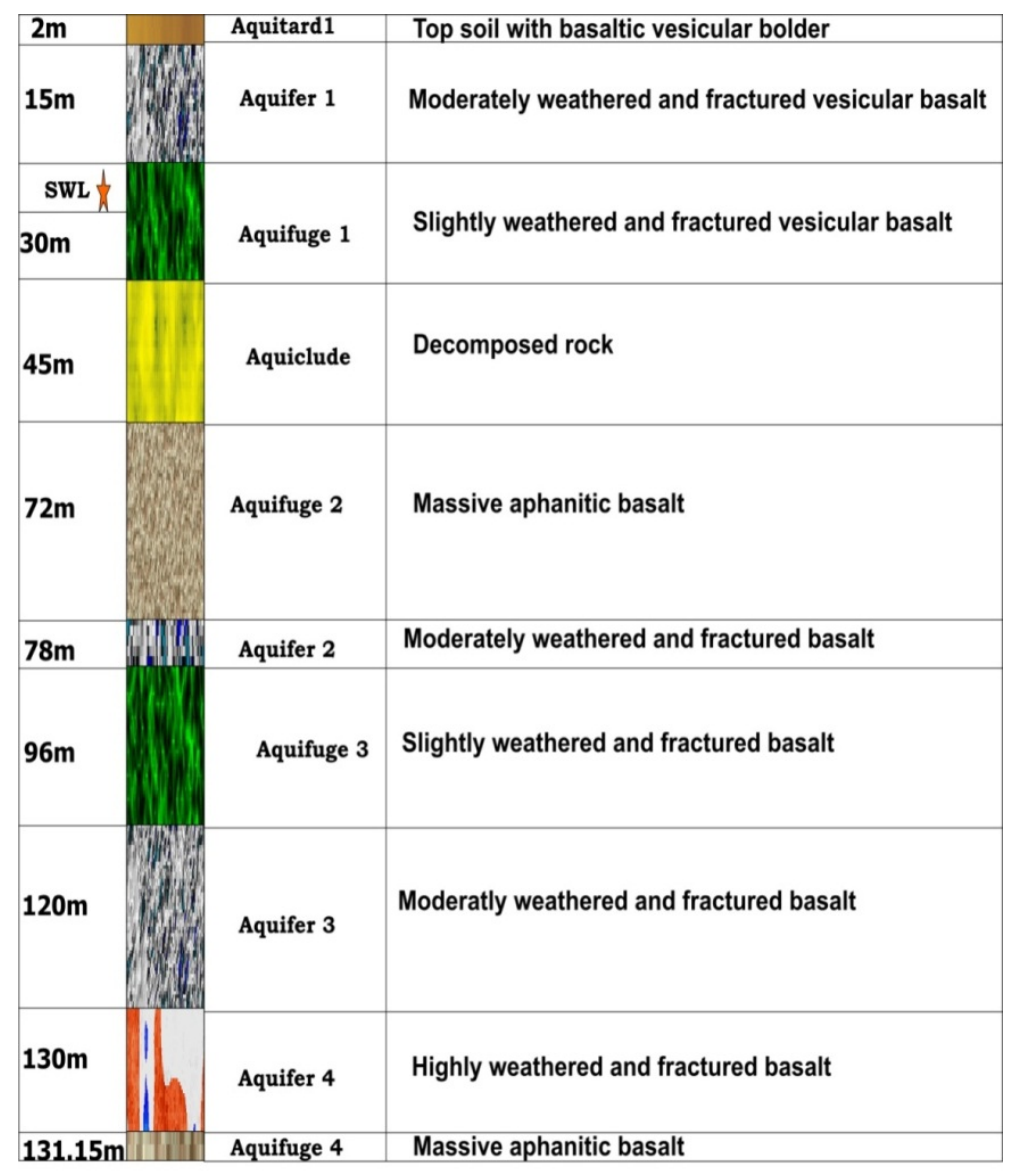

V.S.: $1: 546$

Figure 11. Geological versus hydrogeological log of well drilled in multilayer confined aquifer (Ashiraf\#2 well) 
At present, ten deep wells and three shallow wells have been drilled in this formation. The hydrogeological logs of these wells also revealed that multilayer confined aquifer is the dominant aquifer type (Fig. 11). Twelve gravity springs and 6 thermal or hot springs are found issuing from this formation. The thermal springs are situated and aliened almost parallel to faults that existed in the study area. Among thermal or hot springs, five of them are geyser and the remaining one is fumarole. The gravity springs are depression, contact and fracture springs.

\subsubsection{Vesicular Basalt}

This unit is found in low elevated areas ranging from $2181-1400 \mathrm{~m}$ asl with the majority falls between 1400 and $2005 \mathrm{~m}$ asl: covering gorge, undulating areas and gentle slope to flat land areas overlaying the aphanitic basalt. Although this basalt is characterized by the presence of vesicles, the importance of these vesicles as a primary porosity and permeability is highly controlled by secondary filling and poor networking of the vesicles.
However, the importance of this unit as a groundwater reservoir is enhanced by the effect of secondary processes. As it is revealed from the lithological logs of a number of boreholes drilled on it, the water bearing zones are the weathered zones and fractured zones (Fig. 12). Its geomorphological setup also contributed for its groundwater reservoir nature. The discharge area of the basin is covered by this rock.

Presently, twenty one deep well and five shallow wells have been drilled in this formation. Deep wells are tapping groundwater from both the vesicular basalt and the underlying aphanitic basalt whereas the shallow wells are from the water bearing zones of the vesicular basalt. The hydrogeological logs of these deep wells show that the dominant aquifer type is multilayer unconfined-confined aquifers (Fig. 12). Confined aquifer is the dominant aquifer type in the vesicular basaltic aquifer. Nine gravity springs are also found issuing from this formation. Here also the gravity springs are depression, contact and fracture springs.

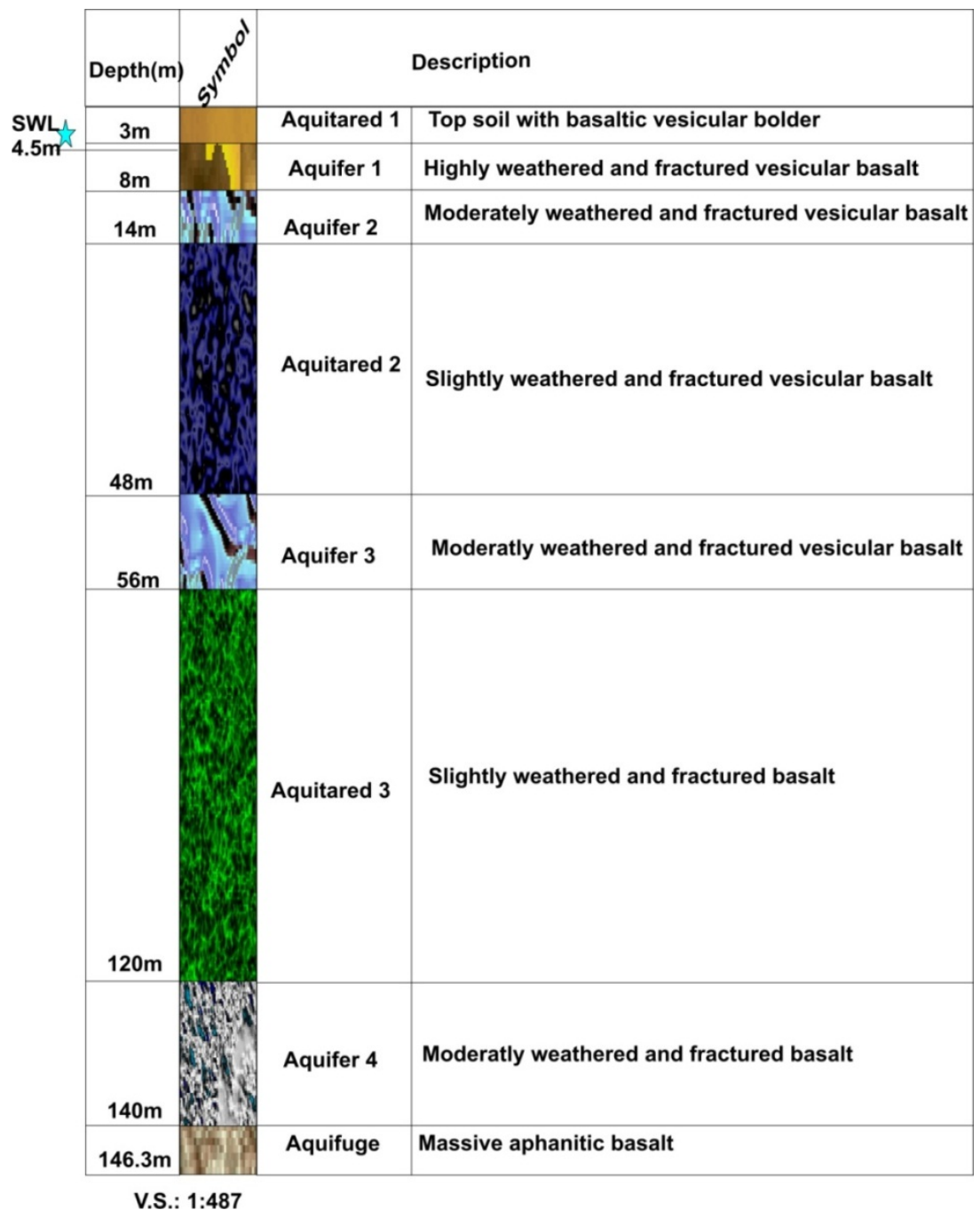

Figure 12. Geological versus hydrogeological log of well drilled in multilayer unconfined-confined aquifers (Amhara Water Works Construction Enterprise (AWWCE) Well) 


\subsubsection{Aquifer Hydraulic Properties}

The basic aquifer properties that were considered for evaluating the aquifer potentiality are the transmissivity (T), hydraulic conductivity (K) and specific capacity. Among the inventoried wells, 8 wells have full pumping test data (provisional, step drawdown test, constant rate test and recovery tests and geological logs), two wells have imperfect pumping test data, 3 wells have provisional test data only, 23 wells have geological logs data only, and 2 wells are abandoned. Out of the eight wells with full pumping test data six of them are in both vesicular and aphanitic basalts having a multilayer unconfined-confined aquifer type, one in aphanitic basalt of multilayer confined aquifer type and the remaining one is in vesicular basalt having confined aquifer type. The pumping test data of these wells were analyzed and the aquifer hydraulic properties were determined.

Accordingly, the computed values of the hydraulic conductivity for the multilayer unconfined-confined aquifers range from 0.165 to $49 \mathrm{~m} /$ day with mean value of $9.599 \mathrm{~m} /$ day and transmissivity ranges from 11.30 to 3870 $\mathrm{m}^{2} /$ day with a mean value of $691.733 \mathrm{~m}^{2} /$ day. The result of the analyses also revealed that specific capacity ranges from 0.164 to $30.968 \mathrm{l} / \mathrm{sec} / \mathrm{m}$ with mean value of 5.63788 $1 / \mathrm{sec} / \mathrm{m}$. The computed hydraulic conductivity, transmissivity and specific capacity for the multilayer confined aquifer are $0.525 \mathrm{~m} /$ day, $10.9 \mathrm{~m}^{2} /$ day and 0.190 1/sec/m, respectively. The hydraulic conductivity, transmissivity and specific capacity for the confined aquifer in the vesicular basalt are $6.46 \mathrm{~m} /$ day, $148 \mathrm{~m}^{2} /$ day and $1.363 \mathrm{l} / \mathrm{sec} / \mathrm{m}$, respectively.

This variation of aquifer properties in the basaltic aquifers is due mostly to variations in the degree of weathering, intensity of fracturing, weathered zone thickness, fractured zone thickness, degree of interconnectivity of fractures, secondary fillings in the fractures and vesicles, and the geomorphological setup constituted by the rocks.

In this research, based on the analyzed results of transmissivity and specific capacity, an attempt was made to classify the aquifers of the study area into different class of potentiality. This classification was made on the basis of Şen [2] scheme (Table 1).

Accordingly, the volcanic rocks of the study area are grouped into three aquifer potentiality groups (Fig. 13). These are:

1. High potentiality aquifer (multilayer unconfined-confined aquifers: the vesicular basalt and the underlying aphanitic basalt together)

2. Moderately potentiality aquifer (confined aquifer: vesicular basalt aquifer only); and,

3. Low potentiality aquifers (multilayer confined aquifer: the underlying aphanitic basalt only).

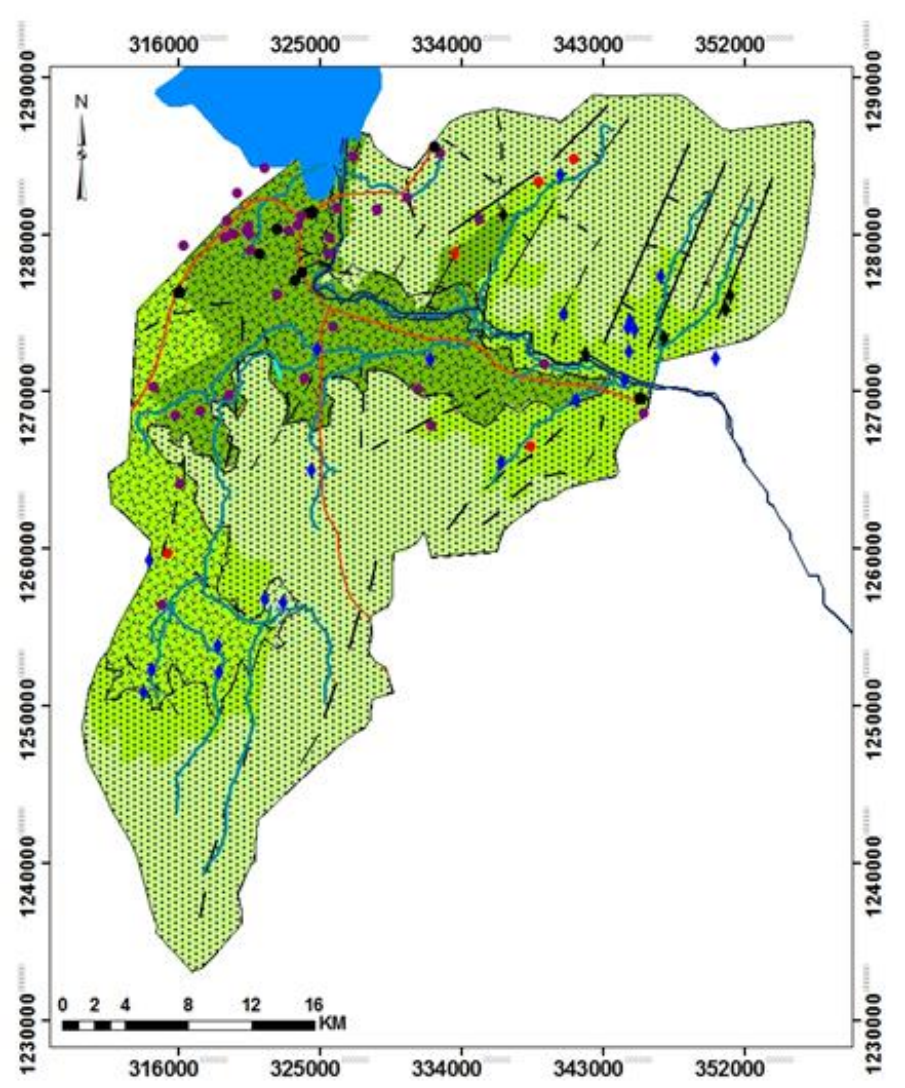

Legend

- Towns

- Shallow_Wells

- Normal_springs

- Hot_springs

- Hand_dag_Wells

- Gas_spring

- Deep_Wells

Roads

- Abay_river

_ Perneal_rivers

— Faults \& Lineaments

Lake_tana

boundary

Geology

Quaternary Vesicular_basalt

Ashangi basalt(Tertiary)

Aquifer classification

Highly_Productive_aquifer

$\mathrm{T}=3640-3870 \mathrm{~m} 2 / \mathrm{d}, \mathrm{Q}=13-48 \mathrm{l} / \mathrm{s}$

Moderately_Productive_aquifer

$T=148-190 \mathrm{~m} 2 / \mathrm{d}, Q=14-341 / \mathrm{s}$

Low_to_weak_productive_aquifer

$\mathrm{T}=4.98-45.2 \mathrm{~m} 2 / \mathrm{d}, \mathrm{Q}=0.5-3 \mathrm{l} / \mathrm{s}$

Figure 13. Hydrogeological map of the study area 


\subsubsection{High Potentiality Aquifer}

This aquifer is formed dominantly by weathered and fractured zones of vesicular basalt and the weathered and fractured zones of the underlying aphanitic basalts together. It is found in northern, northwestern, western, north-central and eastern parts of the study area, occupying low land and gently undulated areas. In the northern part the aquifer is recharged by Lake Tana. Generally, this aquifer group is found covering the discharge areas of the basin where most of the boreholes are drilled.

Eighteen deep wells were inventoried in this aquifer group. The depths of the wells range from 97 to $174 \mathrm{~m}$. The thickness of the aquifers ranges from 29 to $87 \mathrm{~m}$ with a mean thickness of $53 \mathrm{~m}$; static water level ranges from 3.81 to $39.63 \mathrm{~m}$; and, the discharge range from $4.5 \mathrm{l} / \mathrm{s}$ to $481 / \mathrm{s}$ with a mean discharge of $18.5 \mathrm{l} / \mathrm{s}$.

\subsubsection{Moderately Potentiality Aquifer}

This type of aquifer is formed dominantly by the vesicular basalt only and is found in the northwestern, western, eastern and southwestern parts of the study area occupying areas that range in elevation from 1839 to $2181 \mathrm{~m}$ asl.

Three deep wells, four shallow wells, one hand dug well and nine gravitational springs were inventoried in this aquifer group. The depth of the wells range from 52.5 to $74.3 \mathrm{~m}$ with a mean depth of $65.9 \mathrm{~m}$, aquifer thickness range from 23 to $35 \mathrm{~m}$, static water level ranges from 3 to 8 $\mathrm{m}$ and the yields of the wells range from 5 to $33 \mathrm{l} / \mathrm{s}$ with a mean discharge of $16 \mathrm{l} / \mathrm{s}$. The gravitational springs are contact, depression and fracture springs with a discharge ranging from 3 to $10 \mathrm{l} / \mathrm{s}$ having an average discharge of 4.6 $1 / \mathrm{s}$.

\subsubsection{Low Potentiality Aquifer}

This aquifer group is formed by weathered and fractured zones of the aphanitic basalts only and is found mainly in the central, eastern, southeastern, southern, northeastern and northern parts of the study area occupying topographically high, sloppy areas and low lands. The northern, northeastern and southern parts are the recharge zones of the basin. They are characterized by highly elevated volcanic ridges and geological structures which are the most important factors that lead the water to drain towards the discharge areas. Structures such as NE-SSE faults and lineaments play a great role by facilitating the recharge process as evidenced by the emergency of several springs at the adjacent low lands.

Ten deep wells, one shallow well, four hand dug wells, twelve gravitational springs and six hot springs were inventoried in this aquifer group. The depths of the deep wells range from 62 to $201.3 \mathrm{~m}$, thickness of the aquifer ranges from 34.85 to $68 \mathrm{~m}$, static water level ranges from 3 to $27 \mathrm{~m}$, and the yield of the well range from 0 to $501 / \mathrm{s}$ with a mean yield of $12.43 \mathrm{l} / \mathrm{s}$. Two abandoned wells were identified in this aquifer types because of extremely low discharge. The yield of the four hand dug wells and a shallow well range from 0.5 to $2 \mathrm{l} / \mathrm{s}$. The discharge of the gravitational springs ranges from $0.5 \mathrm{l} / \mathrm{s}$ to $3 \mathrm{l} / \mathrm{s}$.

\section{Conclusions}

This study was conducted in the upper part of the Blue Nile basin with an objective of characterizing the different volcanic rocks aquifers and evaluation of their respective productivity for future sustainable development of groundwater in the basin. The basin is drained by the Blue Nile River and its tributaries. The central, eastern and northwestern parts are characterized by gentle slope undulating and low land areas whereas the southwestern, southern and northeastern parts are highly elevated, steep slope mountainous areas. Lake Tana, which is the southern boundary of the basin, is a recharge source to the basin.

Geologically, the basin is covered by Tertiary flood basalt, which is aphanitic in texture, and Quaternary basalt, which is vesicular in texture. The aphanitic basalt covers $72.67 \%$ of the total study area and occurs in the north, northeastern, eastern, southeastern, southern, southwestern and central parts whereas the vesicular basalt covers $27.33 \%$ of the total study area and is found in the central, western, northwestern, southwestern and eastern parts of the study area. Secondary processes have enhanced the porosity and permeability of these rocks to be groundwater reservoirs. In both these formations, the weathered zones and fractured zones are the water bearing zones. Analyses of pumping test data of the water bearing zones revealed the existence of three types of aquifers: confined aquifer, multilayer confined aquifer and multilayer unconfinedconfined aquifer. Aquifer hydraulic properties for each aquifer type were determined. Accordingly, the computed values of the hydraulic conductivity for the multilayer unconfined-confined aquifers ranges from 0.165 to 49 $\mathrm{m} /$ day with mean value of $9.599 \mathrm{~m} /$ day and transmissivity ranges from 11.30 to $3870 \mathrm{~m}^{2} /$ day with a mean value of $691.733 \mathrm{~m}^{2} /$ day. The result of the analyses also revealed that specific capacity ranges from 0.164 to $30.968 \mathrm{l} / \mathrm{sec} / \mathrm{m}$ with mean value of $5.63788 \mathrm{l} / \mathrm{sec} / \mathrm{m}$. The computed hydraulic conductivity, transmissivity and specific capacity for the multilayer confined aquifer are 0.525 $\mathrm{m} /$ day, $10.9 \mathrm{~m}^{2} /$ day and $0.190 \mathrm{l} / \mathrm{sec} / \mathrm{m}$, respectively. The hydraulic conductivity, transmissivity and specific capacity for the confined aquifer in the vesicular basalt are $6.46 \mathrm{~m} /$ day, $148 \mathrm{~m}^{2} /$ day and $1.363 \mathrm{l} / \mathrm{sec} / \mathrm{m}$, respectively.

Three types of aquifer potentiality groups were identified in the basin based on the analyzed results of transmissivity and specific capacity: high potentiality aquifer (multilayer unconfined-confined aquifers: the vesicular basalt and the underlying aphanitic basalt together), moderately potentiality aquifer (confined aquifer: vesicular basalt aquifer only), and, low potentiality aquifers (multilayer confined aquifer: the underlying aphanitic basalt only). 
Sustainable groundwater resource development and management should take place in the discharge area of the basin, which is covered by high potentiality aquifer by considering the whole thickness of multilayer unconfined-confined aquifers. These areas are northern, northwestern, western, north-central and eastern parts of the basin. Moderately potentiality aquifer can also be used for small scale water supply in rural areas.

\section{Acknowledgement}

The authors duly acknowledge Amhara Water Well Drilling Enterprise for sponsoring this research work. The authors also extend their acknowledgment for Amhara Design and Supervision Works Enterprise for providing secondary data and necessary supports.

\section{REFERENCES}

[1] Kruseman G.P. (1990). Analysis and evaluation of pumping test data, Second edition, International Institute for Land Reclamation and Improvement, Wageningen, The Netherlands.

[2] Şen, Zekâi. (1995). Applied Hydrogeology for Scientists and Engineers. CRS Press, Lewis Publishers, London, pp. 444.

[3] Mohr P.A. (1962). Stratigraphy and correlation of Cenozoic volcanic rocks. Geological Survey of Ethiopia, Addis Ababa, pp. 26.

[4] Zanettin, B., Gregnanin, A., Justin Visintin, E., Mezzacasa, G. and Piccirillo, E.M. (1974). Petrochemistry of the volcanic series of the central-eastern Ethiopian plateau and relationship between tectonics and magmatology, Mem. 1st. Miner. Univers. Padova, 31: pp. 1-35.

[5] Mohr, P. (1983a). Ethiopian flood basalt province. Nature 303 , pp. $577-584$

[6] Mohr, P., and Zanettin, B. (1988). The Ethiopian flood basalt province. In J.D. Macdougall, Ed., Continental Flood Basalts, pp. 63-110. Kluwer Academic, Dordrecht.

[7] Zanettin, B. (1993). On the evolution of Ethiopian volcanic province, from Geology and Mineral Resources of Somalia and Surrounding Areas. Ist. Agron. Oltremare, Firenze, Relaz. E Monogr. 113, pp. 279-310.

[8] Pik, R., Deniel, C., Coulon, C., Yirgu, G., Hoffmann, C. and Ayalew, D. (1998). The northwestern Ethiopian Plateau flood basalts: classification and spatial distribution of magma types. Journal of Volcanology and Geothermal Research: 81, pp. 91-111.

[9] Ayalew, D., Marty, B., Yirgu, G. \& Pik, R. (1999). Geochemical and isotopic ( $\mathrm{Sr}, \mathrm{Nd}$ and $\mathrm{Pb}$ ) characteristics of volcanic rocks from southwestern Ethiopia. Journal of African Earth Sciences 29, pp. 381-391.

[10] Kazmin, V. (1975). Explanation of the geological map of Ethiopia. Ethiop. Geol. Surv. Bull., 1, pp. 1-15.
[11] Piccirillo, E., Justin Visentin, E., Zanettin, B., Joron, J. L. and Treuil, M.(1979). Geodynamic evolution from plateau to rift: major and trace element geochemistry of the central eastern Ethiopian Plateau volcanics. Neues Jahrbuch für Geologie und Paläontologie, Abhandlungen 158, pp. 139 179.

[12] Hofmann, C., Courtillot, V., Feraud, G., Rochette, P., Yirgu, G., Ketefo, E., and Pik, R. (1997). Timing of the Ethiopian flood basalt event and implications for plume birth and global change. Nature, 389, pp. 838-841.

[13] Yirgu, Y. (1997). Magma-crust interaction during emplacement of Cenozoic volcanism in Ethiopia: Geochemical evidence from Sheno-Megezez are central Ethiopia. SINET Ethiopian Journal of Science, 20 (1): pp. 49-72.

[14] Pik, R., Deniel, C., Coulon, C., Yirgu Marty, B. (1999). Isotopic and trace element signatures of Ethiopian flood basalts: evidence for plume-lithosphere interactions. Geochim. Cosmochim. Acta 63, pp. 2263-2279.

[15] Baker, J., MacPherson, C. G., Menzies, M. A., Thirlwall, M. F., Al-Kadasi, M. and Mattey, D. P. (2000). Resolving crustal and mantle contributions to continental flood volcanism, Yemen; constraints from mineral oxygen isotope data. Journal of Petrology 41, pp. 1805 - 1820.

[16] Baker, J., Chazot, G., Menzies, M. A. and Thirlwall, M. (2002). Lithospheric mantle beneath Arabia: a Pan-African protolith modified by the Afar and older plumes, rather than a source for continental flood volcanism. In: Menzies, M. A., Klemperer, S. L., Ebinger, C. J. \& Baker, J. (eds) Volcanic Rifted Margins. Geological Society of America, Special Papers 362, pp. 65 - 80.

[17] Bruno Kieffer, Nicholas Arndt, Henriette lapierre, Florence Bastien, Delphine Bosch, Arnaud Pecher, Yirgu, G., Ayalew,D., Weis,D., Jerram,D.A., Keller, F. and Meugniot, C. (2004). Flood and shield Basalts from Ethiopia: Magmas from the African Suuperswell. Journal of Petrology, Vol. 45, No. 4, pp. 793-834.

[18] Kurkura Kabeto (2010). Geological and geochemical variations in Mid-Tertiary Ethiopian Flood Basalt Province, Maychew, Tigray Region, Ethiopia. Momona Ethiopian Journal of Science, Vol. 2, No. 1, pp. 4-25.

[19] Prave A.R., Bates C.R., Donaldson C.H., Toland H., Condon D.J., Mark D., and Raub T.D. (2016). Geology and geochronology of the Tana Basin, Ethiopia: LIP volcanism, super eruptions and Eocene-Oligocene environmental change. Elsevier, Earth and planetary Science Letters 443, pp. 1-8.

[20] Chorowicz J., Collet B., Bonavia F.F., Mohr P., Parrot J.F. and Korme T. (1998). The Tana Basin, Ethiopia: intra-plateau uplift, rifting and subsidence. Tectonophysics 295, pp. 351-367.

[21] Gani N.DS., Abdelsalam M.G., Gera S. and Gani M.R, (2009). Stratigraphic and structural evolution of the Blue Nile Basin, Northwestern Ethiopian Plateau. Geological Journal, Geol. J.44: pp. 30-56. 